\title{
Från maninnor till cyborger: Hur feminister har skaffat sig språklig makt
}

\section{Karin Milles}

Min artikel handlar om feministisk språkplanering och språkaktivism under hundra år, framför allt utifrån en svensk horisont. Jag ska försöka dra upp några viktigare utvecklingslinjer, diskutera idémässiga rötter och framtiden.

Min artikel har fyra delar. För det första vill jag ge några belysande exempel på hur feminister $^{1}$ genom åren har använt språket för att bedriva politik. Feminister har länge använt språket för sina syften - de har grundat tidskrifter, skrivit böcker, formulerat slagord och rent allmänt höjt sina röster för att höras.

För det andra vill jag också ge några exempel på hur de inte bara har använt språket för sina syften, utan också försökt initiera förändring när det visat sig att språket inte har passat deras syften. De har bedrivit regelrätt språkplanering och medvetet påverkat andras språk och språkbruk: lärt ut mötesteknik, infört nya pronomen och utvecklat nya språkliga praktiker. Jag kommer också att peka på hur språkplaneringen hela tiden har samspelat med det språksamhälle den bedrivits i, de mål feministerna just då kämpat för och det motstånd de mötte.

Efter denna, naturligtvis mycket översiktliga, historiska översikt kommer jag för det tredje att diskutera de teoretiska rötterna till de olika insatser feministerna har gjort. Här menar jag att det finns två strömningar som framförallt har influerat, gett kraft och riktning: svensk språkvård och feministisk teoribildning. Hur man inom dessa fält tänker kring språkets funktion och natur har påverkat, lika väl som hur de har tänkt kring kvinnor, kvinnlighet och kön.

Artikelns fjärde och sista del ägnas frågan om på vilket sätt feministernas förhållande till språket och språkfrågor är intressant för oss språkvetare. Vad finns det för oss som forskare att undersöka och beskriva här, hur ska vi göra det och kanske viktigast av allt - varför ska vi göra det?

\section{Att använda språket för att bedriva politik}

Låt oss först ta ett stort kliv på drygt 100 år bakåt i historien. Sverige var då ett land i stark omvandling. Ny teknik möjliggjorde nya kommunikationssätt: järnvägen byggdes ut, industrierna växte, tidningsmarknaden expanderade kraftigt. Och helt nya grupper av människor började kliva fram, organisera sig och kräva sin rätt. Det är där vi finner maninnorna. Vilka var nu det? Låt oss se på några exempel.

Från början var maninna bara en femininform av man, dvs. kvinna. Enligt Bibeln var det Adam som kom på benämningen. När han första såg Eva sa han nämligen: ’Detta är dock ben af mina ben och kött af mitt kött. Hon skall heta maninna, därföre att hon är tagen af mannen" (Bibeln, Första moseboken 2:23, 1878).

\footnotetext{
${ }^{1}$ I artikeln använder jag på vissa ställen beteckningen feminist i vid bemärkelse eftersom jag gör en exposé ända från rösträttsrörelsen, då den beteckningen ännu inte var etablerad, till dagens läge då den är den vanligaste.
} 
Men under förrförra sekelskiftet, när kvinnorörelsen började göra sig hörd på allvar, började benämningen också användas särskilt om de kvinnor som kämpade för sina rättigheter. I Gustaf Cederschiölds beryktade funderingar om kvinnospråkets särskilda egenskaper menar han ju exempelvis att det bara var kvinnor "i den självständiga klass, som kallats 'maninnorna', 'de emanciperade' o.d." som använde slang (Cederschiöld 1900:33). Ett annat exempel kommer från ett sagolustspel, skrivet av Frans Hedberg, en nu glömd men då mycket framgångsrik dramatiker, några år senare. Lustspelet handlar om en smålänning som sluter en pakt med djävulen och får fara framåt i tiden. I framtiden har utvecklingen gått framåt: Ladugårdsgärdet i Stockholm är bebyggt och folk har lindat koppartråd runt magen för att kunna ta emot telefonsamtal när de är ute och går. Det kanske mest omvälvande är att kvinnorna har tagit över:

Joo, nog finns det riksdagar men inga riksdagsmän mera - bara riksdagsmaninnor. Karlarna äro fockade från det politiska lifvet och nu är det kvinnorna som regera världen! (Hedberg 1906:89)

Citaten visar att kvinnosakskvinnorna både sågs som normbrytande och som ett hot. Benämningen maninna verkar ha använts på ett mer eller mindre raljerande sätt och var inget som kvinnosakskvinnorna själva använde.

Men när kvinnorörelsen formerade sig för att utkämpa sin första riktigt stora strid, den om rösträtten, la de mycket energi på att ta makten över språket. För att samla rörelsen och sätta kraft bakom sina politiska krav använde de många olika språkliga strategier: de startade tidningar, skrev artiklar, höll föredrag och arrangerade namninsamlingar (Florin 2006:145).

Och de höll möten. I romanen Pennskaftet av Elin Wägner, som handlar om en grupp rösträttskvinnor, beskriver huvudpersonen upplevelsen av ett rösträttsmöte så här:

Du vet man gaskar upp varandra vid de stora mötena, när man är tusen, som vill samma sak, vi hade talare ur alla partier, och jag var vild av entusiasm, o jag skulle utföra stora saker, det var roligt att arbeta, att leva, att vara med just nu -- (Wägner 1910:105)

Möten är kraftfulla politiska redskap som kan fungera som en kraftsamlande rit som skapar energi och fokus för deltagarna (Collins 2004). Detta kunde verkligen behövas för rösträttskvinnorna, som upptäckte att deras kamp blev mycket längre och hårdare än de hade föreställt sig från början.

Det handlade inte bara om att arrangera egna möten, föredrag och diskussioner för att skapa sammanhållning och kraft. För att få genomslag för sin politik måste rösträttskvinnorna också häva upp sina röster på männens politiska möten, där besluten om kvinnornas medborgarvärdighet skulle tas. Och det, insåg man inom rörelsen, var inte lätt för alla kvinnor, som hade uppfostrats till att, som det heter i Bibeln, "tiga i församlingen". För den sakens skull lät man mötesövningar ingå som en del i de många medborgarkurser som arrangerades för att förbereda kvinnorna för den kommande medborgarrollen och visa för rösträttsmotståndarna att kvinnorna var både redo och kunniga nog. Under dessa kurser fick deltagarna inte bara lära sig grunderna i statskunskap, hur den svenska fackföreningsrörelsen var uppbyggd och de olika ståndpunkterna i den så kallade sedlighetsfrågan. De övades också i att hålla föredrag, leda möten och delta i politiska diskussioner. Man tryckte också upp och spred möteshandledningar för de många lokala rösträttsföreningar som bildades. Kvinnorna uppmuntra- 
des att arrangera studiecirklar och fingerade möten för att öva sig i politisk praktik (för en närmare beskrivning, se Milles 2017).

Också efter att kvinnor för första gången kunde utnyttja sin vunna rätt att rösta 1921 fortsatte kvinnorörelsen att lära nya generationer kvinnor att våga och kunna delta $\mathrm{i}$ politiska möten. På den kvinnliga medborgarskolan på Fogelstad instiftades den fiktiva kommunen Komtemåtta under varje kurs. Alla kursdeltagarna tilldelades en roll i kommunen, som ordförande i kommunstyrelsen, prost etc. och skulle sedan styra kommunen tillsammans. Fogelstad, och gruppen som gjorde skolan möjlig, finns beskriven bland annat i Knutson 2004.

Det här är bara ett exempel på hur kvinnorörelsen har erövrat det offentliga språket för att driva sin politik. Och det var inte bara den muntliga arenan som erövrades. Kvinnorna hade också en genomtänkt mediestrategi för att använda det framväxande massmediesamhället i kampen för sina rättigheter. Så såg man till att få medietäckning och bjöd in journalister till de föredrag och möten som rörelsen arrangerade. Elin Wägner är här återigen ett bra exempel. Hon arbetade också som journalist och var en av dem som regelbundet rapporterade om rösträttsrörelsens aktiviteter i de tidningar hon arbetade för, Idun och Dagens Nyheter. Hon var dock inte den enda journalisten som skrev om kvinnokampen, men det var särskilt kvinnliga journalister som såg till att ge rösträtten täckning i tidningarna (Ney 2001).

För att få kontroll över vad som skrevs i spalterna och driva sina frågor på ett fokuserat sätt startade kvinnorörelsen dessutom egna tidskrifter. Den tidigaste av dessa var Tidskrift för Hemmet, som startades redan 1859 i syfte att öka bildningsnivån bland de svenska kvinnorna och diskutera kvinnofrågor. Den har följts av tidskrifter som Hertha, Vi kvinnor, Tidevarvet, Kvinnobulletinen, Bang och nu senast den feministiska nättidningen Feministiskt perspektiv, för att bara nämna några av de mer kända. (För mer om kvinnotidskrifter, se Nordenstam 2014.)

Vi kan alltså se att kvinnorörelsen, liksom alla politiska rörelser, har använt den offentliga arenans resurser för att göra sin röst hörd. De kvinnliga aktörerna inom rörelsen såg till att behärska den offentliga arenans genrer, medel och kanaler för att skaffa sig inflytande i den offentliga debatten och tillträde till de maktens rum där de viktiga besluten tas. Detta var resultatet av genomtänkta strategier, och en ansenlig mängd tid och kraft lades ner på arbetet.

\section{Att förändra inifrån}

Det här var en bitvis mycket framgångsrik strategi. Men när kvinnorna så äntligen hade garanterats fullständig medborgarstatus och både kunde rösta och röstas in i landets alla beslutande församlingar, märkte de att detta inte var slutet på kampen. För det första var det ganska få kvinnor som faktiskt blev inröstade, för det andra hade de ofta svårt att få gehör för sin politik. Urgamla, sega strukturer omöjliggjorde ofta all verklig förändring.

Och det här gällde också språket. Det var ett språk skapat av och för män. Det språk, de genrer, de mönster för kommunikation som användes på den offentliga arenan och i maktens innersta korridorer, de osynliggjorde ofta kvinnors närvaro och erfarenheter, och fråntog dem den makt de nu åtminstone på papperet hade fătt tillgång till.

Men när man väl är inne i systemet, då kan man börja förändra det. Nästa steg blev alltså att börja ifrågasätta strukturerna, att förändra dem och att ibland skapa helt egna, nya. Eller som gruppen Tjejclown sjunger 1974: 
Det växer ett språk

Starkt ur våra strupar

Våra kroppar har en kraft av visshet om vår styrka

Och all den kunskap som föraktats och stulits, gömts

har börjat visa sig i våra tankar

(text: Anne Lidén)

Jag ska nu ge tre exempel på detta, och börjar med hur man började diskutera mötesformer.

Mötesgenren var alltså något man alltsedan rösträttskampen hade siktat in sig på i kvinnorörelsen. Då hade fokus varit att lära sig behärska alla samtalsformer och all formalia. Men med tiden började man också inrikta sig på formen för mötena och diskutera huruvida det fanns element i själva mötessamtalet som snarare än befriande, faktiskt var förtryckande. Grundfrågan var om mötesformen i sig reproducerade hierarkier och tystade viktiga röster. Under sjuttiotalet ifrågasatte exempelvis Barbro Backberger från Grupp 8 stormötesformen, som hon menade "var den mest odemokratiska form man kunde ha för det var bara de som kunde ta för sig som dominerade och styrde debatten" (Witt-Brattström 2010:59). Den här diskussionen, och andra, ledde till att man inom olika kvinnoaktivistiska sammanhang började utarbeta alternativa sätt att mötas och fatta beslut. Ett exempel på alternativa samtalsformer är så kallade rundor och basgrupper. Dessa började användas exempelvis på Kvinnohöjden, en folkhögskola av och för kvinnor som startade 1981 och som fortfarande har en levande verksamhet. Så här skriver de själva på sin hemsida:

Vi vill bryta ner det traditionella auktoritetsmönstret mellan olika roller och ge utrymme för allas erfarenheter. Viktigt är att varje kvinna får möjlighet att känna sig trygg, välkommen och respekterad i gruppen. En hörnsten i vår verksamhet är rundorna, där var och en får säga sin mening utan att bli avbruten eller ifrågasatt. Vi delar också in oss i basgrupper, små ledarlösa grupper, där vi har möjlighet att fördjupa oss i det som känns viktigt. (kvinnohojden.se)

Det finns tyvärr inte så mycket språkvetenskapligt inriktad forskning om det här, och det jag har kunnat hitta är pedagogiska beskrivningar (exempelvis Sundbro \& Törnegren 1984 och Törnegren 2013), men jag tror definitivt det finns mycket att beskriva och diskutera utifrån ett mer språkvetenskapligt och samtalsteoretiskt perspektiv.

För det andra sattes fokus på orden, som snabbt visade sig färgade av att samhället styrts av män. Språket hade helt enkelt inte ord för den nya verklighet där också kvinnor skulle vara med, finnas till, spela roll, diskutera och bestämma. Ett exempel här är titlar och yrkesbenämningar, som ofta var tydligt markerade för kön. När kvinnorna kämpade sig in på traditionellt manliga områden upptäckte de snabbt att de benämningar och titlar som fanns var tydligt manliga. När de första kvinnorna tog plats i riksdagen 1922 fick de göra det som riksdagsmän, exempelvis. Kvinnors unika erfarenheter och verksamhetsfält verkade också liksom försvinna ur ordförrådet: den kvinnliga sexualiteten tystades ner genom att beröva flickor och kvinnor på orden för sina kön, och traditionellt kvinnliga domäner var underrepresenterade i de normerande ordböckerna (Mattisson 2006, Kram 1998, Milles 2009).

Denna insikt har lett till en mängd förslag på nya ord, och dessa förslag kan sägas följa i huvudsak två strategier: den könsneutrala eller den könsspecifika (Lindgren 2007, Wojahn 2015). Ett exempel på den könsneutrala linjen är lösningen på riksdagsmans-problematiken. Sedan några decennier kan vi nog säga att titeln riksdagsledamot har etablerats för både män 
och kvinnor. Se figur 1, som visar utvecklingen i svensk presstext för orden riksdagsman, riksdagskvinna och riksdagsledamot.

Det kanske mest välkända nya könsneutrala ord vi fått i svenskan är nog hen, som funnits i svenskan åtminstone sedan 1960-talet, men inte började diskuteras på allvar förrän i början av 2000-talet. Då började genuspedagoger, feminister och htbq-aktivister ungefär samtidigt använda och försöka etablera ordet med en högljudd massmedial debatt som följd. Nu, 2016, har debatten ebbat ut och ordet används i många olika sammanhang som i reklamkampanjer, tidningstexter och studentuppsatser.

I hen:s kölvatten började också en del byta ut det obestämda pronomenet man mot en. Detta bruk har för närvarande viss spridning särskilt bland unga feministiskt orienterade personer i både tal och skrift. Men det förekommer också i en hel del medier med radikal profil som det gröna nyhetsmagasinet Syre, RFSU:s tidskrift Ottar och de feministiska Bang och Feministiskt perspektiv. ${ }^{2}$

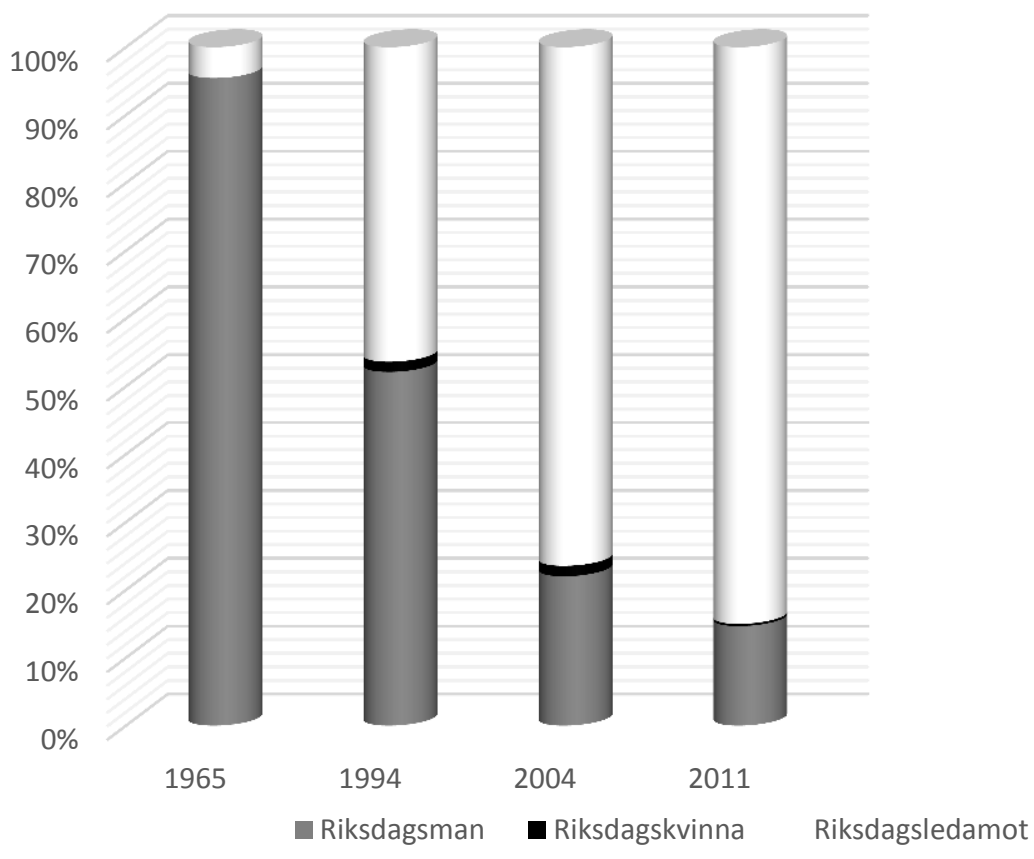

Figur 1. Användningen av titlarna riksdagsledamot, riksdagskvinna och riksdagsman i svensk presstext 1965 till 2011, uttryckt i procent.

Men också en könsspecificerande strategi har använts: man har lanserat nya kvinnliga ord, framförallt för specifikt kvinnliga företeelser, som när man har spritt ordet snippa för flickors och kvinnors kön (Milles 2006) eller slidkransen som en ny och mer rättvisande benämning för det som traditionellt har kallts mödomshinna (Milles m.fl. 2017).

Hur kvinnorörelsen har diskuterat och introducerat nya ord och benämningar i Sverige under de senaste decennierna har rönt mycket uppmärksamhet också inom forskningen, se

\footnotetext{
${ }^{2}$ Vid mejlförfrågan till dessa tidningars redaktioner har de alla sagt att de låter skribenterna välja uttryckssätt själva.
} 
bland annat Hornscheidt 2015, Ledin \& Lyngfelt 2013, Lind Palicki \& Milles 2015, Milles 2006, 2011, 2013, Milles m.fl. 2017, Rancken 2015, Wojahn 2015, Ängsal 2015).

För det tredje har feminister börjat diskutera inte bara nya mötesformer och nya ord, utan också nya sätt att skriva. Som en del i sökandet efter en egen röst och ett eget språk har feministiska skribenter börjat utveckla nya stilar och kanske rentav nya genrer. Detta är dock relativt obeforskat från språkvetenskapligt håll, och jag ska därför endast ta exempel från en för oss ganska välkänd domän: den vetenskapliga. Inom de feministiska och genusvetenskapliga disciplinerna har en hel del av de etablerade stilideal och genrekrav som ställts på akademisk text blivit ifrågasatta, och nya som bättre ska kunna bidra till det feministiska emancipatoriska projektet har utvecklats. Så här uttrycker sig Ulrika Dahl, docent i genusvetenskap vid Södertörns högskola, i inledningen till sin essäsamling Skamgrepp:

Denna bok som nu är i din hand eller på din skärm är den första som jag skrivit med modersmål i mun, mus och tangentbord. Även om formen är ny och Skamgrepp är min första är varken hon eller jag särskilt nya till vårt innehåll. I mitt försök att välkomna dig som läsarinna till denna skrift kan jag inte låta bli att också tänka på den betydelse som "första gången" alltid tycks ha i den feminina tillblivelsen. Första förförelsen eller överträdelsen, första gången du har sex, första boken, de framställs alla ofta som särskilt viktiga och minnesvärda; något att längta efter (eller rädas) och något som ska kännas på ett speciellt sätt; förväntansfullt, mystiskt, roligt (eller traumatiskt). (Dahl 2014:18)

Även om boken är en essäsamling och utgiven på ett förlag som vill rikta sig till en läsekrets utanför den snäva ämnesdisciplinen, är den också klart vetenskaplig i sina ambitioner då texterna utgår från bland annat queerteori och feministiska teoretiker som Sara Ahmed, Judith Butler och Hélène Cixous. Den innehåller både notapparat och litteraturlista.

Men samtidigt har texten flera drag som gör att den bryter mot rådande genrekrav för mycket akademisk prosa. Här ska bara nämnas några. Kanske att ett direkt läsar-tilltal kan skrivas på essä-kontot, men man behöver inte ha läst Althusser för att lägga märke till att läsaren här blir ovanligt tydlig i konturerna då den ges både kropp - eller åtminstone en hand - och kön som läsarinna (Althusser har blivit känd för att ha rett ut hur ett tilltal, eller en interpellation, av en person också är med och skapar personens identitet. Se vidare Althusser 1976).

Texten bryter också stilistiskt mot akademiprosans objektiva ideal som sällan uppmuntrar författaren att synas. I det citerade stycket syns hon ganska tydligt genom de många referenserna till sig själv som görs bland annat genom pronomen i första person singularis ("jag skrivit", "min första", "varken hon eller jag", "kan jag inte låta bli”). Också stilistiskt lyser en personlighet igenom, då Dahl är mycket mer stilistiskt yvig än en akademiker vanligtvis tillåter sig att vara. Här kan vi särskilt lägga märke till den sista långa grafiska meningen som är fylld med hopningar, tillägg och upprepningar. Detta tillsammans med ordlekar, allitterationer och andra stilistiska drag gör texten både flödande och rolig att läsa. I utdraget ovan syftar exempelvis ordet mus ganska tydligt på datortillbehöret, men på andra ställen i boken leker hon med dess både dubbla och trippla betydelser som datortillbehör, djur och kvinnligt kön:

Att tänka med musen är samtidigt ett näbbigt och otidsenligt sätt att i dessa nyliberala tider fortsätta att insistera på att erfarenheten av att födas in i ett "man eller mus" samhälle, där att tilldelas eller kallas för mus förblir ett uttryck för svaghet och brist ...(Dahl 2014:359) 
Allt det här verkar mycket medvetet. Det sista avsnittet handlar om skrivandet som frigörelseprojekt och inleds med ett citat av Elspeth Probyn: "Ibland verkar det som om akademiker inte aspirerar på att vara författare" (Dahl 204:351). I avsnittet frågar Dahl också läsaren om den blivit provocerad "av att ha tilltalats i femininum" (Dahl 2014:351), och hon bjuder in till ett vidare samtal. Dahl kallar sitt skrivande för "femme-inint skrivande" (Dahl 2014:19). Hon anknyter därmed explicit till de franska feministerna (mer om dem nedan), och skriver fram skrivandet som en del i det feministiska frigörelseprojektet, där berättande i många olika självbiografiska skepnader ses som en viktig resurs.

Dahl är inte ensam. Inom Sveriges högskolevärld diskuteras detta nya skrivsätt inom ramen för så kallat reflexivt skrivande, och kopplingen till genusvetenskapen är oftast stark. Förutom att det hållits seminarier och symposier där gränserna för det akademiska skrivandet diskuteras och tänjs, finns det också en hel del publikationer som diskuterar ämnet, exempelvis böckerna Genusforskning - en guide till feministisk teori, metodologi och skrift (Lykke 2009), Genus och det akademiska skrivandets former (Bränström Öhman \& Livholts 2007), Emergent Writing Methodologies in Feminist Studies (Livholts 2012), Kreativt skrivande och kritiskt tänkande i genusvetenskap (Lundberg \& Werner 2014) och ett specialnummer av Tidskrift för genusvetenskap, TGV (2008). Denna diskussion har också trådar bakåt - kanske särskilt inom skönlitteraturen har kvinnor och kvinnorörelsen länge diskuterat skrivande som frigörelseakt (mer om detta nedan), men här är det alltså skrivandet som vetenskaplig metod som står i centrum.

Trots att språkvetenskapen rymmer mycket intressant skrivforskning, och en hel del sådan som fokuserar särskilt på akademiskt skrivande, verkar den här diskussionen framförallt hållas inom andra vetenskapsdiscipliner som sociologi, genus- och litteraturvetenskap. Det är synd. Jag tror att språkvetenskapligt skolade skrivforskare skulle kunna bidra med intressanta perspektiv på det vetenskapliga skrivandets funktioner, former och samhälleliga kontext här. Också textteorier som placerar in texter i ett sociokulturellt sammanhang borde kunna bidra på liknande sätt.

Detta för oss över på den tredje delen av artikeln, där jag ska försöka placera in det feministiska språkarbetet i ett vidare sammanhang och diskutera dess rötter och teoretiska kopplingar.

\section{Språkaktivismens två rötter}

Jag ska nu försöka, åtminstone översiktligt, att diskutera möjliga ideologiska rötter till feminismens och feministers förhållande till språkplanering, språkaktivism, språkliga uttryck och skrivande. Jag är medveten om att jag här målar med en bred pensel. Men kanske finns det också en poäng i just detta, då översikten kan göra behovet av nyansering och komplettering tydligt.

De exempel på hur feminister genom åren har erövrat och i vissa stycken förändrat språkliga uttryck, genrer och praktiker som jag gett här har hela tiden ingått i ett sammanhang. De har ofta varit svar på förtryckande strukturer eller varit tänkta som strategiska projekt med emancipatorisk potential. De har också varit inbäddade i sin tids politiska landskap med dess handlingsmönster, dess ideologiska och teoretiska strömningar. Sålunda är det inte konstigt att rösträttskvinnorna fokuserade på möteskompetens - möten av olika slag var viktiga arenor 
för politisk handling på den tiden, och många av de samtidiga folkrörelserna arbetade på liknande sätt med att bygga upp föreningar och träna sig i hur offentligt talande och skrivande. Se exempelvis Josephson 1996 för en beskrivning av hur detta gick till i arbetarrörelsen. Och under sjuttiotalet var det fler än kvinnorna i kvinnorörelsen som ifrågasatte hierarkier och utarbetade nya mötesstrukturer. Särskilt vänsterrörelsen i bred bemärkelse och internationell feminism gav den svenska rörelsen tankar och impulser. (Se exempelvis beskrivningar i Hallgren 2008, Isaksson 2007, Witt-Brattström 2010 och Elgán 2015.)

Men detta handlar om de yttre politiska strömningarna och det samhällsklimat som rådde vid olika tidpunkter. Går det också att säga något mer specifikt om språkideologiska influenser? Vilken syn på språk, språklig handling och språkets politiska implikationer har inspirerat, väglett eller gett verktyg när feministerna diskuterat språkets roll i kvinnors underordning och motståndsstrategier?

Jag skulle vilja säga att de språkideologiska strömningarna kan delas upp i två huvudfåror, där den ena är den svenska språkvården, och den andra är feministisk teoribildning.

Låt oss ta språkvårdsspåret först. Här handlar det om att de feminister som velat förändra exempelvis kvinnors språkliga osynliggörande har kunnat ta stöd i den svenska språkvårdens arbete för klarspråk, dvs. tanken att den offentliga svenskan av demokratiska skäl ska vara inte bara vårdad, utan också klar och begriplig. Historiskt sett har det inte funnits något större samröre mellan den organiserade kvinnorörelsen och den organiserade språkvården, utan de kopplingar som funnits har varit mer slumpvisa och beroende på enskilda personer.

Jag ska inte gå in i detalj på historiken här. Den finns beskriven på annat håll (se exempelvis Lindgren 2007, Lind Palicki \& Milles 2015 och Wojahn 2015). Men sammanfattningsvis kan kanske sägas att språkvården nog har spelat störst roll när det gäller feministernas kamp för mer inkluderande uttryckssätt och yrkestitlar och då genom att ganska genomgående förorda könsneutrala formuleringar.

Det andra spåret, som är mer vildvuxet och från svensk språkvetenskaplig horisont definitivt mer obeforskat, är det feministiska spåret. Det ska jag ägna lite större utrymme.

Feministiska teoretiker har nämligen ofta varit påfallande intresserade av språkets roll i könsförtrycket, och de kan ofta sägas följa det större postmoderna spåret, den så kallade språkliga vändningen (the linguistic turn). Den språkliga vändningen innebär fokus på hur språket inte bara avbildar, utan också aktivt är med och skapar verkligheten: "Language generates reality in the inescapable context of power; it does not stand for or point to at knowable world hiding somewhere ...”, skriver Donna Haraway (1991:78, mer om henne nedan).

Härifrån är det inte långt till tanken att könet är en del av den verklighet som skapas genom språket. Eller som feministikonen Simone de Beauvoir uttryckte det i sin epokgörande bok Det andra könet: "Man föds inte till kvinna, man blir det." Och om könet är något som skapas i det sociala sammanhanget av bland annat språkets strukturer och bruk, då är det heller inte långt till tanken att språket också kan användas för att initiera förändring. Det är därför inte att förvåna att många feminister har ägnat just språket en hel del uppmärksamhet när de har diskuterat motstånds- och förändringsstrategier. Den första jag ska nämna, men som jag sedan inte ska gå in på närmare, är filosofen Judith Butler. Hon lånade nämligen begreppet performativitet från talaktsteorin (se Austin 1962) och tänkte sig att precis som 
performativa talakter förändrar världen skapar performativa genushandlingar illusionen av ett medfött och stabilt kön (Butler 1990).

Men även om Butler för en del resonemang om benämningar etc. finns det andra feministiska teoretiker som tydligare sätter språket i centrum också för motståndsstrategierna. Och jag ska här genom tre inflytelserika tänkare försöka ringa in tre viktigare teoretiska strömningar, för att något litet visa på bredden i de här tankarna.

För det första vill jag här nämna den feministiska kommunikativa etiken, där jag låter den amerikanske feministiska statsvetaren Iris Marion Young stå för ett belysande citat. Så här skrev hon:

Invånarna måste sluta upp bakom en princip om ömsesidig respekt för varandra - i den enkla formella betydelsen att man är beredd att acceptera allas rätt att utrycka sina åsikter, och att alla bör lyssna. (Young 2000:158)

Med stöd i Habermas teori om deliberativ demokrati, som i korthet handlar om hur människor i ett gott samhälle kan komma överens genom saklig diskussion i stället för genom maktkamp, utvecklar hon tankar om hur kommunikationen i ett sådant samhälle måste utformas för att detta ska fungera. Centralt här är alla människors rätt att uttrycka sig och de personliga berättelsernas möjlighet att ge alla en unik röst. Hon och andra med henne poängterar dialogen och samtalens roll för att vi människor ska kunna leva väl tillsammans trots fundamentala olikheter. Det ska inte vara de med de starkaste rösterna som vinner. I samhället ska allas röster räknas, såväl de starka som de svaga, och detta kan direkt kopplas till Kvinnohöjdens rundor som jag nämnt ovan, där alla gavs utrymme i samtalet, i tur och ordning och på lika villkor. En annan som också har utvecklat den kommunikativa etiken är filosofen Seyla Benhabib (se exempelvis Benhabib 1992).

Dessa två teoretiker anlägger ett brett samhällsperspektiv, medan andra har haft en mer specifik inriktning på det kvinnliga och på hur kvinnor mer på ett individplan ska kunna förändra sin situation på ett mer individuellt plan. Här kan de franska så kallade écriture féminine-teoretikerna placeras in.

Hélène Cixous har redan nämnts ovan, låt oss ta henne som exempel. Hon är litteraturvetare, filosof, författare och skapare av den så kallade poststrukturella feministiska filosofin tillsammans med Julia Kristeva och Luce Irigaray. Så här visionärt placerar hon in skrivandet i den feministiska frigörelseprocessen:

Jag kommer att tala om den kvinnliga skriften: om vad den kommer att göra. Kvinnan måste skriva sig själv: kvinnan måste skriva kvinna och låta kvinnorna komma till skriften /.../ Kvinnan måste ta plats i texten - liksom i världen och i historien - genom sin egen rörelse. (Cixous 1996:238)

Skrivandet blir mer än ett sätt att kommunicera, den blir ett sätt att bli till. Cixous och de övriga franska feministerna har dragit synen på språket som något som är skapat av och för män till sin spets. Här handlar det inte om att språket innehåller enstaka osynliggörande ord och uttryck, utan här handlar det om att den manliga principen så till den milda grad genomsyrar hela språkstrukturen att det som kvinna överhuvudtaget inte går att tala. Talar en kvinna så gör hon det genom det manliga, falliska språket. För att återfå sin röst måste kvinnor skapa ett eget språk och skriva fram sig själva inom detta. Speciellt är att Cixous så tydligt förankrar 
detta skrivande i en kvinnlig, reproduktiv kropp, då kvinnan "skriver med vitt bläck", alltså modersmjölk (Cicoux 1996:244). Här är inte platsen att i detalj beskriva denna teoribildning. En grundlig genomgång finns i Moi 1985, och en feministisk kritik av det finns i Cameron 1985 och Fraser 1992. Här kan det vara nog att poängtera de franska feministernas betonande av skrivandet som motståndshandling och den kraft de ser i huvudsak i det skrivna ordet. Kvinnor ska och måste skriva fram sitt eget språk, sin egen litteratur. Genom detta kan de förändra kvinnans ställning.

Det är naturligtvis inte förvånande att den feministiska litteraturvetenskapen länge har förhållit sig till dessa tankar. Men det har alltså också feministiska akademiker från andra discipliner gjort, som exempelvis den tidigare nämnda Ulrika Dahl, som ser möjligheten att det feministiska akademiska skrivandet inte bara kan driva den feministiska vetenskapen framåt. Det kan också ha kraft att befria den feministiska forskaren själv.

Jag ska avsluta med några ord om Donna Haraway, och det innebär att vi nu är framme vid cyborgen i artikelns titel. Den tidigare nämnda Haraway, vetenskapsteoretiker med en bakgrund inom zoologi och teknikvetenskap, har på senare år varit mycket inflytelserik inom feministisk teoribildning. Hon har ofta ifrågasatt vetenskapens anspråk på total objektivitet. Som citatet ovan avslöjar misstror hon också språkets förmåga att beskriva verkligheten. Hon menar att det snarare är så att vetenskapen berättar fram denna verklighet. Detta berättande, menar Haraway, är ovillkorligen färgat av uråldriga patriarkala sätt att se på världen, att förstå den och kanske framförallt att dela upp den i kategorier. Språket är inte ett neutralt medium, utan ett politiskt verktyg: "Grammar is politics by other means" (1991:3), skriver hon exempelvis. Och precis som många feminister före henne låter hon analysen av ursprunget till de förvridna maktförhållandena bli utgångspunkten för en diskussion om det möjliga motståndet: "how can we develop reading and writing practices, as well as other kinds of political work, to continue to contest for the material shapes and meanings of nature and experience?" frågar hon (Haraway 1991:4). Precis som för Young och Cixous blir alltså språkliga praktiker, i det här fallet både läsande och skrivande, en del av det politiska motståndet mot olika typer av förtryck. Men det intressanta med Haraway är att hon i centrum för sitt tänkande också sätter teknologin, användandet av verktyg och metoder för att organisera och underlätta våra liv, och hur vi använder denna teknik för att göra kön. Höga klackar är exempelvis en sådan genusteknologi. Skor med höga klackar kan ses som en slags kroppslig protes, som i vår kultur traditionellt skapar kvinnlighet. Också skapandet av kvinnliga och manliga avatarer i tevespel kan ses som genusteknologi. Men vi ska inte bara analysera och kritisera den tekniska utvecklingen, vi ska ta kontroll över den. Och det är här cyborgen, en sammansmältning av människa och robot, kommer in.

Cyborg imagery can suggest a way out of the maze of dualisms in which we have explained our bodies and ourselves. This is a dream not of a common language, but of a powerful infidel heteroglossia. It is an imagination of a feminist speaking in tongues to strike fear into the circuits of the supersavers of the new right. It means both building and destroying machines, identities, categories, relationships, space stories. (Haraway 1991:181).

Cyborgen blir en befriande tankefigur, som hjälper oss att ta kontrollen över tekniken. Haraway drömmer om kraften i en mångfacetterad feminism som ska kunna visa vägen mot en bättre framtid. Den kvinnliga cyborgen blir en respektingivande, mäktig hjälpare i det både 
nedbrytande och uppbyggande arbete som krävs för att få en bättre, mer rättvis, värld. Men den cyborg det handlar om är inte den kvinnliga terminatorn - en robot med ett mänskligt yttre - utan om den datoranvändande feministen. Genom att använda sig av modern informationsteknologi kan kvinnor blir ett slags cyborger, som använder datorn, programvaran och internet för att överskrida tidsliga och rumsliga begränsningar. Haraway är både ekofeminist och antikapitalist och hoppas att denna dröm om en feminist som talar i tungor ska kunna bjuda motstånd mot kapitalistiska krafter genom att skriva fram nya identiteter och nya relationer mellan människor på jorden.

Detta är alltså några feministiska teoretiker vilkas tankar vi kan se spår av hos många av dagens språkaktivistiska feminister. Ett genomgående drag hos dem är att de hör hemma inom andra vetenskapliga discipliner än de språkvetenskapliga: de är filosofer, statsvetare, litteraturvetare, biologer etc. Allt utom lingvister. ${ }^{3}$ Det här är antagligen en av orsakerna till att de inte i någon högre grad utvecklar eller preciserar sina språkliga resonemang eller försöker placera in dem i någon språkvetenskaplig teoribildning, vilket för en språkvetare ofta blir frustrerande.

\section{Två teman för framtida forskning}

Detta för mig över på frågan om hur framtida feministisk språkvetenskaplig forskning kan utformas. Underrubriken på min artikel är "hur feminister har skaffat sig språklig makt", och genom att börja med maninnan, den hånade tidiga feministen, och avsluta med cyborgen, denna potenta vision av en radikal feministisk identitet, vill jag illustrera ett historiskt förlopp. Jag har också pekat på några forskningsluckor och gett förslag på forskningsuppgifter, och här går det att urskilja två övergripande teman: teoretiska rötter och praktisk tillämpning.

Det första temat, de teoretiska rötterna, handlar om hur vi borde fördjupa vår kunskap om - för att travestera Haruki Murakamis populära bok Vad jag pratar om när jag pratar om löpning - vad feminister pratar om när de pratar om språk. Den genomgång jag gett ovan bör ha visat att här finns det mycket intressant att undersöka. De feministiska teoretiker som menar att språket spelar en viktig roll i både skapandet av könsstrukturer och i vårt arbete med att förändra dem, vad har de för språksyn egentligen? Vad menar de med språk, och hur ser de på språkets förhållande till allt annat - samhälleliga, sociala strukturer, identitet, makt? Hur hänger deras språksyn ihop med språkvetenskapens beskrivning? Anknyter de till språkvetenskapens centrala teman eller ser de på språk på radikalt andra sätt? Ovan har jag bara gett några ytligt beskrivna exempel. Här finns mycket mer att göra. En djupare förståelse för de teoretiska grunderna skulle inte bara komplettera beskrivningen av den feministiska språkaktivismens ursprung och uttryck. Det skulle också utveckla den feministiska lingvistikens teoribildning.

Det andra temat skulle vara frågan om hur denna språkliga aktivism ser ut i sin praktik. Vad händer när de feministiska teorierna mötet aktivismen? Mycket av den redan befintliga forskningen har intresserat sig för språkaktivism på ordnivå: nya benämningspraktiker, bruk av pronomen och liknande. Men minst lika intressant tycker jag det är med den aktivism som handlar om att förändra språkliga praktiker på ett mer övergripande plan: hur feminister har

\footnotetext{
${ }^{3}$ Därmed naturligtvis inte sagt att det inte finns feministiska lingvister som diskuterar språkaktivism (se exempelvis Cameron 1990, 1985).
} 
förändrat mötesrutiner och använder rundor inom sina olika organisationer, hur nya pronomen fungerar i de feministiska och aktivistiska kommunikationsgemenskaperna etc.

Och särskilt viktigt tycker jag att det vore att närmare undersöka det feministiska akademiska skrivandet, eftersom det som allt akademiskt skrivande har en särställning i samhället i och med de särskilda anspråk på mening och vetenskaplighet som det har. Akademiska texter är med och bygger upp ett samhälles självförståelse och historia.

Hur diskuterar lärarna skrivande med studenterna på de genusvetenskapliga utbildningarna utifrån de feministiska teoretikerna? Vilka textuella följder har deras idéer för texterna - tentorna, skrivuppgifterna, uppsatserna - som skrivs där? Är det gamla textmönster som används i nya sammanhang eller är det nya mönster som utvecklas? Vilka sociala och kognitiva funktioner har de texttyper och genrekonventioner som uppmuntras? Och hur går de nya textidealen ihop med de teorier och metoder för akademiskt skrivande som är etablerade på andra håll inom högskolevärlden? Finns det konfliktytor - vad händer exempelvis en genusstudent som möter andra akademiska ideal i andra ämnen?

Även om jag naturligtvis på intet sätt vill påstå att det feministiska projektet är avslutat och att vi numera lever i ett jämställt paradis, har de senaste 100 åren ändå inneburit oerhört omvälvande förändringar av kvinnors situation. En hel del kraftfullt motstånd mot de patriarkala strukturerna har mobiliserats. Det är nog inte för mycket sagt att säga att feministisk politik och praktik under de senaste hundra åren har haft mer inflytande än någonsin tidigare under historien. Min genomgång ovan har också förhoppningsvis visat att språket har spelat en roll i både politik och praktik. Historien om hur en av vår tids mest inflytelserika politiska rörelser har påverkat - och fortsätter att påverka - både språk och språkbruk är något som vi som språkvetare definitivt borde utforska noggrannare! Inte för att nödvändigtvis utvärdera eller kritisera, utan framförallt för att förstå och kartlägga som en del i vår samtida språkhistoria.

Kanske är det för mycket att säga att jag är "vild av entusiasm" och att utlova storverk som Elin Wägners rösträttskvinna i citatet i artikelns inledning, men nog är det ändå roligt att vara feministisk språkvetare, att forska och att få vara med just nu!

\section{Referenser}

Althusser, Louis. 1976. Ideologi och ideologiska statsapparater. I: Filosofi från proletär klasståndpunkt. Staffanstorp: Cavefors.

Austin, John Langshaw. 1962. How to do things with words. Oxford: Clarendon Press.

Beauvoir, Simone de. 2002. Det andra könet. Stockholm: Norstedts. [Franskt original 1949.]

Benhabib, Seyla. 1992. Autonomi och gemenskap. Kommunikativ etik, feminism och postmodernism. Daidalos: Göteborg.

Bibeln. 1878. Bibelkommissionen. Finns åtkomlig via länken: [http://www.bibel.se/bibeln/ andra-bibeloversattningar/bk-1878-gt_1057l .

Bränström Öhman, Anneli \& Mona Livholts (red.). 2007. Genus och det akademiska skrivandets former. Lund: Studentlitteratur.

Butler, Judith. 1997. Det performativa könet. I: Res Publica. Symposions teoretiska och litterära tidskrift. Nr 35/36. S. 13-23.

Butler, Judith. 1990. Gender trouble. Feminism and the subversion of identity. New York \& London: Routledge.

Cameron, Deborah. 1985. Feminism and Linguistic Theory. London: Macmillan. 
Cameron, Deborah. 1990. The Feminist Critique of Language: A Reader. New York: Routledge.

Cederschiöld, Gustaf. 1900. Om kvinnospråk och andra ämnen. Anteckningar och reflektioner. Lund: Gleerup.

Cixous, Hélène. 1996 [1975]. Medusas skratt. I: Johanna Esseveld, \& Lisbeth Larsson (red.): Kvinnopolitiska nyckeltexter. Lund: Studentlitteratur. S. 238-246.

Collins, Randall. 2004: Interaction ritual chains. Princeton, N.J.: Princeton University Press.

Dahl, Ulrika. 2014. Skamgrepp. Femme-inistiska essäer. Stockholm: Leopard förlag.

Elgán, Elisabeth. 2015. Att ge sig själv makten. Grupp 8 och 1970-talets feminism. Göteborg: Makadam.

Florin, Christina. 2006. Kvinnor för röst. Kön, känslor och politisk kultur i kvinnornas rösträttsrörelse. Stockholm: Atlas.

Fraser, Nancy. 1992. The uses and abuses of French discourse theories for feminist politics. I: Nancy Fraser \& Sandra Lee Bartky (red.): Revaluing french feminism. Critical essays on difference, agency, and culture. Bloomington and Indianapolis: Indiana University Press.

Hallgren, Hanna. 2008: När lesbiska blev kvinnor. Göteborg: Kabusa böcker.

Haraway, Donna. 1991. Simians, cyborgs, and women. New York: Routledge.

Hedberg, Frans. 1906. Hin och småländingen. Stockholm: Bonniers.

Hornscheidt, Lann. 2015. Trans_x_ing linguistic actions and linguistics. I: Jenny Magnusson, Karin Milles \& Zoe Nikolaidou (red.), Könskonstruktioner och språkförändringar. Rapport från den åttonde nordiska konferensen om språk och kön. Huddinge: Södertörns högskola. S. 29-46.

Isaksson, Emma. 2007. Kvinnokamp. Synen på underordning och motstånd $i$ den nya kvinnorörelsen. Stockholm: Atlas.

Josephson, Olle (red.). 1996. Arbetarna tar ordet. Språk och kommunikation i tidig arbetarrörelse. Stockholm: Carlssons.

Knutson, Ulrika. 2004. Kvinnor på gränsen till genombrott: grupporträtt av Tidevarvets kvinnor. Stockholm: Bonniers.

Kram, Kristina. 1998. "...blott rent undantagsvis om kvinnor". Om representation av kvinnan i moderna ordböcker. Språk \& Stil nr 8 1998. S. 159-171.

Ledin, Per \& Benjamin Lyngfelt. 2013. Olika hen-syn. Om bruket av hen i bloggar, tidningstexter och studentuppsatser. I: Språk \& Stil nr 23. S. 141-174.

Lind Palicki, Lena \& Karin Milles. 2015. Feministisk språkplanering under den andra vågens kvinnorörelse: Exemplen Grupp 8 och den offentliga språkvården. I: Jenny Magnusson, Karin Milles \& Zoe Nikolaidou (red.), Könskonstruktioner och språkförändringar. Rapport från den åttonde nordiska konferensen om språk och kön. Huddinge: Södertörns högskola. S. 145-166.

Lindgren, Birgitta. 2007: Språkvården och könsneutral referens. I: Britt-Louise Gunnarsson, Sonja Enzenberg \& Maria Ohlsson (red.), Språk och kön i nutida och historiskt perspektiv Uppsala: Institutionen för nordiska sprak. S. 237-242.

Livholts, Mona. 2012. Emergent writing methodologies in feminist studies. London: Routledge.

Lundberg, Anna \& Werner, Ann. 2014. Kreativt skrivande och kritiskt tänkande i genusvetenskap. Göteborg: Nationella sekretariatet för genusforskning.

Lykke, Nina. 2009. Genusforskning. En guide till feministisk teori, metodologi och skrift. Stockholm: Liber.

Mattisson, Anki. 2006. Genusperspektiv på SAOB:s källor. I: LexicoNordica. S. 55-68. Milles, Karin. 2006. En jämställd kroppsdel? Om lanseringen av ett neutralt ord för flickors könsorgan. I: Språk \& stil, nr 16: 149-177. 
Milles, Karin. 2009. "Klitoris orsakar orgasm" - kön och sexualitet i svenska ordböcker. I: Tidskrift för genusvetenskap $\mathrm{nr}$ 2-3, 2009. S. 121-137.

Milles, Karin. 2011. Feminist language planning in Sweden. I: A. J. Liddicoat (red.). Current Issues in Language Planning. Vol. 12, nr. 1. S. 21-33.

Milles, Karin. 2013. En öppning i en sluten ordklass? Den nya användningen av pronomenet hen. I: Språk \& Stil nr 23. S. 107-140.

Milles, Karin. 2017. "Vi måste öva upp och ta mod till oss, enda sättet att sedan bli dugliga väljare" Strategiskt kommunikationsarbete inom den kvinnliga rösträttsrörelsen, Språk och stil nr 26 2017. S. 130-160.

Milles, Karin, Holmdahl, Jessica, Melander, Ida, Hjortek, Lisa \& Fugl-Meyer, Kerstin. 2017. "Den som töjs under sex" Ordet slidkrans som sexualpolitiskt verktyg. (I denna volym).

Moi, Toril. 1985. Sexual/textual politics. Feminist literary theory. London \& New York: Routledge.

Ney, Birgitta. 2001. Osynliga förbindelser. Om kvinnliga journalisters dolda insats i rösträttskampen. I: Christer Jönsson (red.), Rösträtten 80 år. Stockholm: Justitiedepartementet. S. 33-42.

Nordenstam, Anna (red.). 2014. Nya röster. Svenska kvinnotidskrifter under 150 år. Möklinta: Gidlunds förlag.

Rancken, Alexis. 2015. Ett "knepigt" men "fenomenalt" pronomen: Förhållningssätt till hen hos personer med queer identitet i Sverige och Finland. I: Jenny Magnusson, Karin Milles \& Zoe Nikolaidou (red.), Könskonstruktioner och språkförändringar. Rapport från den åttonde nordiska konferensen om språk och kön. Huddinge: Södertörns högskola. S. 167-184.

Sundbro, Karin \& Gull Törnegren. 1985. Feministisk pedagogik. Opublicerad c-uppsats. Stockholm: Stockholms universitet. Fanns 2016-02-22 tillgänglig via länken: [http://www.kvinnohojden.se/wp-content/uploads/2014/10/SundbroTornegren1985 Feministiskpedagogik.pdf].

TGV: Tidskrift för genusvetenskap nr. 2. 2008. Fanns 2016-02-23 tillgänglig via länken: [http://dspace.mah.se/handle/2043/8094].

Törnegren, Gull. 2013. Utmaningen från andra berättelser. En studie om moraliskt omdöme, utvidgat tänkande och kritiskt reflekterande berättelser $i$ dialogbaserad feministisk etik. Uppsala: Uppsala universitet.

Witt-Brattström, Ebba. 2010. Å alla kära systrar! Historien om mitt sjuttiotal. Stockholm: Norstedts.

Wojahn, Daniel. 2015. Språkaktivism. Diskussioner om feministiska språkförändringar $i$ Sverige från 1960-talet till 2015. Uppsala: Institutionen för nordiska språk.

Wägner, Elin. 1910. Pennskaftet. Stockholm: Ljus.

Young, Iris Marion. 2000 [1990]. Kasta tjejkast. Stockholm: Atlas.

Ängsal, Magnus P. 2015. Queerande språkkritik: En jämförande analys av argument för svenskans hen och tyskans personsubstantiv med inskjutet understreck. I: Jenny Magnusson, Karin Milles \& Zoe Nikolaidou (red.), Könskonstruktioner och språkförändringar. Rapport från den åttonde nordiska konferensen om språk och kön. Huddinge: Södertörns högskola. S. 185-204.

\section{Andra källor}

Kvinnohojden.se, hemsida för den feministiska kursgården Kvinnohöjden. Hämtat den 2 mars 2017.

Lidén, Anne. 1974. Det växer ett språk. Från skivan Tjejclown - livmoder i strängarna garanterat utan stake. MNW. Skivnummer MNW 48P. 